\title{
The Feasibility of Infiltration and Method of Chinese National Music in Piano Teaching
}

\author{
Jun Su \\ Department of Music, Chengdu Normal University, Chengdu, Sichuan, 610000, China
}

Keywords: National music, Piano teaching, Infiltration, Feasibility

\begin{abstract}
In our country during the piano teaching, the teachers and the students are pursuit for the chapters such as Beethoven's piano Sonata , Chopin 's Etude, Rachmaninoff's Prelude. In order to enhance the student's piano skills, reflect the teaching quality, the teachers take these foreign music as the ultimate goal and carry out teaching, However, in this process, the teachers have neglected the importance of national music in the teaching of piano. In the course of teaching, we pay attention to the teaching and the western culture.
\end{abstract}

\section{Introduction}

China has a long history of five thousand years.The culture and art carries the essence and connotation of the generation, which contains a wealth of knowledge and art. Combination of folk music is a form of culture and art,which embodies the strong national spirit of our country, including the enduring Chinese historical stories, all inclusive. The penetration of folk music in our country piano teaching can enable students to experience the rich cultural heritage of China, perennial national spirit, with Western musical instruments playing Chinese folk music can let the students experience the Chinese folk music in the piano keyboard percussion shocking, to cultivate students' sense of national pride and national honor.

\section{The connotation of Chinese national music}

Folk music originated from the folk, spread in the folk, which is the portrayal of people's lives, have a strong national characteristics of art form [1]. China's long history greatly enrich the national music culture, make it in the stream of the development and progress of time endless. For Chinese national music understanding, which is not enough just by listening to China songs, traditional music , but also pay attention to the penetration of national music in various fields, to examine folk music from the historical, geographical and other point of view, the understanding of ethnic music, so as to know the profound connotation of national music China [2]

\section{The characteristics of Chinese national music}

Chinese national music has experienced the baptism of historical development, which is the collection of different regional music, however, whether it is a genre, genre, variety, or national, regional differences, the overall characteristics and connotation of Chinese national music is consistent with the characteristics of folk music, the line, harmony and artistic conception is unified, harmonious.

Musical line. Lines of Chinese folk music is dominated by linear mode of thinking about music, and to pay attention to the forms of tunes, outstanding music melody changes, rich tone. Chinese folk music melody contains different accent and dialect, different regions, different times have different tune and tone, and the art of calligraphy and painting art, dance art integrated showed elegant line art, adjust the volume, length adjustment, timbre transformation, transformation passages such as to show the different artistic emotion [3], therefore, folk music, the line is beautiful, sources in the treatment of monosyllabic. Another source in the decoration of the melody.

Musical harmony. Chinese national music is beautiful, highly integrated and natural, geographical embodies Chinese national music world of nature. the Chinese national music is free 
and unfettered, no rules of music, belonging to the non logical forms of art, like the story of the Chen Shuyi like natural, elegant, gave birth to the scene of a beautiful natural ecology, local customs, folk music of harmony will reflect this. Therefore, in most national music, the variation, transforms, reproduction and other means to reflect the national music soothing and harmony.

The artistic conception of music. Chinese folk music is melodious, make people relaxed and happy, because that national music fully reflects the author for the pursuit of artistic conception. At the same time, Chinese folk music attaches great importance to the music itself, vivid effect, the form of cultural transmission is usually "oral", whether it is author of folk music composing, performing, or people on the national music listen to and enjoy. Is from the point of view of the artistic conception, sense by the unique charm of the beauty of artistic conception given music, people the highest pursuit of beauty.

\section{The present situation and the reason analysis of the piano teaching in our country}

Present situation of piano teaching in China. In recent years, with the strengthening of efforts of national attention to the cause of education, the reform and innovation of the piano teaching in our country has also been widespread concern in the education sector, folk music has gradually penetrated into the piano teaching in our country, for example, the many piano competition, competition system provides the play works to integrate into the Chinese folk music, which in a certain extent promoted the China National Music in piano teaching penetration [4]. However, in combination with the current situation of piano teaching, the importance of national music for piano teaching has not attracted the attention of teachers and students.

At present, many provinces in China in order to strengthen the national music in the piano teaching in the infiltration, the Chinese piano works in the piano teaching program, but in the preparation of the teaching syllabus, still in the western music, in which Chinese piano works can be said to be minimal. The survey found that many teachers and students for the Chinese piano works have a bias, that the piano teaching should be based on western music, Chinese folk music fusion can not achieve its pursuit of the beauty of the piano music. Therefore, teachers in the teaching process, or to teach western music based, students also lack the awareness and desire to play Chinese piano works, resulting in the Chinese national music piano playing seriously insufficient, resulting in the Chinese national music in the specific teaching of poor penetration.

\section{Reason analysis.}

Less creation of music

The integration of Chinese national music and piano playing requires that the melody and the piano playing of the national music should be integrated, and the Chinese piano works which are suitable for Piano playing. At present, many piano players in China are limited in the creation of Chinese piano works, which lead to the Chinese national music in the piano teaching in China. According to incomplete statistics, at present the Chinese piano works only about 400 , in which only 100 are familiar to students the many works are based on the traditional music adapted, for example: "Moon", "meihuasannong" etc., due to these works by the shackles of the traditional folk music thought, in piano music adapted efforts seriously insufficient, resulting in folk music in Piano Teaching in the penetration is greatly restricted.

The teaching system is not complete

Chinese piano art formation time was in 1934, the shepherd boy's Piccolo, "Lullaby" is the formation of the iconic works [5]. From the formation of the Chinese piano art has been more than 70 years of history, but in this 70 years, the development of piano art in China has not been widespread concern, in the piano teaching for national music teaching penetration is very limited. At present, our country piano teaching materials is still dominated by the western music, piano teaching in many western countries are combined with their own conditions and development of teaching, and in the piano teaching in China, with the lack of piano teaching system with Chinese characteristics, leading to teachers don't teach, students cannot learn the teaching situation. 
Not enough attention to the national music culture

The China piano works to western music for piano is fewer,.Thw teacher have less selective ethnic music, it is difficult for teachers to experience China importance for national music. Piano teaching is ignored if things go on like this, will penetrate into the China folk music in the piano teaching process, students have not formed the national consciousness in Piano learning, in many teachers and students in the eyes of western music, is "highbrow", and Chinese folk music is "popular literature or art," this wrong understanding leads to both teachers and students are lack of the importance of national musical culture, which China folk music can't get good inheritance in piano teaching.

\section{The necessity of Chinese national music in Piano Teaching}

Penetration of national music is the need for the development of Chinese Piano Teaching. The importance of Chinese national music for piano teaching is beyond doubt, which is not only the need of the development of Chinese piano, but also the direction of the international piano teaching research. In recent years, the Chinese piano education has become more and more focused on national culture, so that the value of Chinese characteristic culture in piano education should carry forward the Chinese national music, and the national culture and national spirit into the piano teaching in our country.

Penetration of national music is the need for the localization of Chinese Piano Teaching. National music is full of culture and art. The contents of piano works in our country are very extensive and the theme is rich, almost all the Chinese piano music theme comes from the folk stories or to the creation of the national music melody adaptation, through the creation and adaptation, the rich national rhythm of the music is full of national flavor and vitality. National music is based on the creation of five tones, in the creation of piano music, for the national music playing in the techniques have a higher pursuit, so that it fully reflects the characteristics of national music. The fusion of national culture and piano teaching is not only the embodiment of the internationalization of Chinese national culture, but also the bridge of the piano teaching and the times. The penetration of national music in the piano teaching, so that students fully understand the connotation of the Chinese national culture, and understand the classical and elegant Chinese national music, so that it is in the process of playing Chinese piano works, the local culture, to achieve the students' positive recognition and understanding of national music.

\section{Method of puting the Chinese national music in the piano teaching}

Strengthen the national consciousness and national concept of penetration. The deviation of the students' understanding of the national music, the fundamental reason lies in the lack of national consciousness and national concept, therefore, in the specific piano teaching, teachers should strengthen the cultivation of students' national consciousness and national ideas, enhance their national culture and national honor. In addition, teachers should also in the teaching process, from the piano learning enlightenment, junior, intermediate and advanced stage to increase the teaching of Chinese piano works, to help students cultivate the fun of playing Chinese piano works, forming a good habit, so that students in the process of playing, understand China's great national spirit.

Improve the teaching material content, enrich the teaching system. Currently in our country piano teaching material is very limited, teaching contents are single and old-fashioned, lack of new ideas and Piano Teaching in our country, lack of clear teaching system, stereotyped form of the teaching, inhibit the infiltration of Chinese national culture in the piano teaching, want to change this situation need every piano teacher together. For example, teachers can be based on the expression of different music, grading standards, music classification of rich materials, collection for students to learn, to stimulate students interest in Chinese piano works, and will be incorporated into the teaching materials, the formation of a complete teaching system, rich content, and in the actual teaching process, lead and encourage students to use the piano playing Chinese folk music, Chinese national culture. 
Formulate scientific and reasonable standards for teaching. At present, the teachers pay attention to the training of the students playing skills in Piano Teaching in our country, and it is not conducive to the national music in the piano teaching. Therefore, teachers must set up the main body of the national music in the piano teaching class, emphasize the importance of the national music, formulate scientific and reasonable teaching standards. In the national music learning and playing, training students playing fingering and playing skills, exercise play a reasonable grasp of the rhythm and speed and with the pedal grasp, clear differences between Chinese culture and Western culture and, in order to achieve penetration of Chinese national music in the piano class.

\section{Conclusion}

To sum up, to strengthen the infiltration of the national music in the piano teaching, which not only can realize the Chinese piano teaching times, localization of the teaching ideas, but also can strengthen development and depth of the Chinese national culture in the teaching Based on the characteristics of Chinese national music, this paper makes a thorough analysis of the current situation and causes of the piano teaching in China. As a piano teacher, we have the responsibility and obligation to realize the penetration of Chinese national music, through the combination of national music and piano teaching, cultivate students' interest in Chinese national music, dig out the people's spirit, improve the traditional teaching form and teaching method.

\section{Reference}

[1] Zhou Mei. On the National music inheritance in the piano teaching in Normal University. Education teaching forum2012 (27): 44-46.

[2] Xu Ning. The subject consciousness of Piano teaching in the national music education. Journal of Zhejiang Normal University (SOCIAL SCIENCE EDITION), 2013,28 (5): 118-120.

[3] Liu Ke, Sun Jingmei. Analysis of the national music teaching in Normal University under the local music culture -- Taking Guo Zhihong's "Yunnan folk song five" as an example. National art research, 2014,27 (5): 94-100.

[4] Wang Xiaoxing. Piano teaching should pay attention to the Journal of Chinese works in the application and national music learning. Journal of Guizhou University (Art Edition), 2011,15 (1).74-75.

[5] Guo Aiping. To strengthen the teaching of Chinese piano music, and to improve the national musical Sensibility - the piano academic exchange in Hong Kong has a sense of. Piano art, 2014 (2): $39-40$. 